\title{
PRODUCTION OF LOW SALT FRANKFURTER WITH MICROBIAL TRANSGLUTAMINASE
}

\author{
L. Darnay*, A. Dankovics, B. Molnár, L. Friedrich, Gy. Kenesei and Cs. Balla \\ Department of Refrigeration and Livestock Products Technology, Faculty of Food Science, \\ Corvinus University of Budapest, H-1118 Budapest, Ménesi út 43-45. Hungary
}

(Received: 9 April 2014; accepted: 2 August 2014)

\begin{abstract}
Several scientific papers suggest that microbial transglutaminase (mTG) is capable of reducing the salt content of cured and/or heat-treated meat products (ham, frankfurters, meat ball). These scientific results are not widely known in Hungary, and as a result of this, only little experience was gathered in our meat industry. According to this lack of knowledge, our aim was to lower the curing salt to a still microbiological safe level using mTG by frankfurters, one of the most well-known heat treated meat products in Hungary. The observed technofunctional properties suggest to use mTG enzyme preparation at $0.5 \%$ concentration. This enzyme dosage can reduce the average $1.8 \%$ salt content to $1.6 \%$ and it also may contribute to extended shelf life of popular frankfurters. Our sensorial analysis revealed that the panellists have not found a loss in quality between $1.4 \%$ and $1.6 \%$ salt.

Keywords: low-salt, frankfurters, microbial transglutaminase, sensory analysis
\end{abstract}

Nowadays, consumers worldwide are motivated to decrease their salt intake as it may help to prevent high blood pressure and coronary heart disease. There is already a Hungarian meat factory in Gyula that launched low-fat and -salt frankfurter in April (Gyulahús Ltd.) following this recommendation. Having more results of further research showing effective ways to reach this target, more low-salt products are expected. As we discovered from the international literature, microbial transglutaminase (E.C.: 2.3.2.13., shortly: $\mathrm{mTG}$ ) can be a promising solution as a structure modifier, due to its action of producing Gln-Lys bonds between food proteins (YoKoyAma et al., 2004). LeE and CHIN (2010) reviewed the application of mTG and stated that the enzyme can improve the gelling properties of meat proteins at a low-salt level when it is combined with functional ingredients such as sodium alginate. In this way, mTG can give nearly the same textural and sensorial properties to healthier low-fat/salt meat products as regularly processed meat can. We were mainly interested in discovering the possibilities to make low-salt frankfurters with mTG, because of their popularity in Hungary. Colmenero and co-workers (2005) concluded that when mTG is used with caseinate, $\mathrm{KCl}$, and fibre, it enhanced the physicochemical characteristics of low-salt frankfurters to a level matching with normal ones. As there were no scientific results showing the effect of mTG itself on frankfurters, we focused on describing the changes in their technofunctional properties with enzyme dosage and salt content to give a know-how for health conscientious meat producers.

\footnotetext{
* To whom correspondence should be addressed. Phone: +36-1-438-6059; e-mail: livia.darnay@uni-corvinus.hu
} 


\section{Materials and methods}

\subsection{Pork meat batter}

Pork meat batter was prepared as following: half portion $(235 \mathrm{~g})$ of minced pork meat $(80 \%$ purity) was ground first with half portion $(180 \mathrm{~g})$ of ice cubes, then additives and seasonings were added in four 1-minute-long steps (1. step: 4\% Na-soluprate (tetrasodium pyrophosphate, Solvent Inc., Hungary), 2. step: $1.2-1.8 \%$ salt (nitrite curing salt containing $0.4-0.5 \% \mathrm{NaNO}_{2}$, Salinen Austria AG., Austria), 3. step: remaining half portion of minced pork meat, 4. step: $1.25 \%$ ground dried paprika (Kalocsai Füszerpaprika Ltd., Hungary), 1.2\% ground white pepper (importer: R-Coop 3 Inc., made in Indonesia), $160 \mathrm{~g}$ of pork back fat (5 mm particle size), 5. step: $0.3-1 \%$ TG H-N-F (nominal activity: $42 \mathrm{U} / \mathrm{g}$ protein, Ajinomoto $\mathrm{GmbH}$.). The meat batters were partly analysed (for surface colour, extrusion, adhesiveness) stuffed into $21 \mathrm{~mm}$ diameter cellulose casings (Kalle Hungária Ltd., Hungary) and hand-linked.

\subsection{Frankfurters}

Frankfurters were pre-dried $\left(60{ }^{\circ} \mathrm{C}, 15 \mathrm{~min}\right)$, cooked (until $72{ }^{\circ} \mathrm{C}$ core temperature) and cooled in shower (until $10{ }^{\circ} \mathrm{C}$ core temperature) in CS350 EL type smoking machine (Korax Ltd., Hungary). After drainage, frankfurters were cooled to $5{ }^{\circ} \mathrm{C}$ and stored in vacuumpackage at the same temperature for further investigation.

\subsection{Surface colour}

Cielab values (lightness, $\mathrm{L}^{*}$; redness, $\mathrm{a}^{*}$; and yellowness, $\mathrm{b}^{*}$ ) of pork meat batters and frankfurters were evaluated on a Minolta Chroma Meter CHR-400 tristimulus colour measuring system (Konica Minolta Sensing Inc., Japan). Ten replicates were performed for each formulation.

\subsection{Extrusion and adhesiveness}

Extrusion and adhesiveness were measured with the conical measuring head of TA.XTPlus (Stable Micro Systems, Great Britain). The cross-head pushed the $90^{\circ}$ cone probe of spreadability rig with $2 \mathrm{~mm} \mathrm{sec}^{-1}$ speed into the sampling holder. The meat batter samples were tempered to $12{ }^{\circ} \mathrm{C}$ and the measuring time was $90 \mathrm{sec}$. Three replicates of each samples were evaluated using the official software of the instrument called Texture Exponent 32.

\subsection{Water holding capacity}

Water holding capacity (WHC) was measured according to Grau-Hamm method (GRAU \& НАмм, 1953) on pork meat batter.

\subsection{Hardness}

TPA analysis was performed with TA.XTPlus (Stable Micro Systems, Great Britain) and the parameter for hardness was selected to be analysed. Ten frankfurter cores (diam. $=21 \mathrm{~mm}$, height $=12 \mathrm{~mm}$ ) were axially compressed to $70 \%$ of their original height. Force-time deformation curves were derived from a $500 \mathrm{~N}$ load cell applied at a crosshead speed of $2 \mathrm{~mm} \mathrm{~s}^{-1}$. The samples were tempered to $12^{\circ} \mathrm{C}$ and the measuring time was $2 \mathrm{~min}$. 


\subsection{Lipid-peroxidation number (TBA)}

The level of lipid-peroxidation was quantified according to thiobarbituric acid content via TBA-number (PIKUL et al., 1989). According to the recipe, $4 \mathrm{~g}$ of frankfurter was homogenised in $20 \mathrm{ml}$ distilled water for $5 \mathrm{~min}$. The solution was mixed with $5 \mathrm{ml}$ of $25 \%$ TCA. After 30 min of shaking, the sample was centrifuged (5000 r.p.m., 10 min). The supernatant was filtered into an Erlenmeyer flask. The mixture of $3.5 \mathrm{ml}$ filtered solution and $1.5 \mathrm{ml} 0.6 \%$ TBA solution was pipetted into a closable test tube. After boiling in waterbath $\left(100{ }^{\circ} \mathrm{C}\right.$, $30 \mathrm{~min}$ ), the sample was cooled down and evaluated spectrophotometrically at $\lambda_{\max }=532 \mathrm{~nm}$. All samples were carried out in triplicate. Malonaldehyde (MDA) standards were prepared using 1,1,3,3-tetraethoxypropane (TEP). TBA-numbers were expressed as mg of MDA equivalents $/ \mathrm{kg}$ of the product, $\mathrm{MDA}=(\mathrm{y}-0.0175) / 0.0122$.

\subsection{Sensory analysis}

After overnight storage, the samples were evaluated with a trained panel (9-10 members) focusing on flavour, taste, and texture. The attributes were ranked on a 0-100 score scale compared to control sample (see on Figs. 1 and 2), which was fixed at the exact middle of the scale.

\subsection{Statistical analysis}

Paired $t$-probe was used to determine the significant differences at $95 \%$ confidence level.

\section{Results and discussion}

\subsection{Selecting the most suitable enzyme dosage for frankfurters made with $1.8 \%$ salt}

The aim of the research was to follow the effect of $\mathrm{mTG}$ in frankfurters made with usual salt addition.

2.1.1. Surface colour. CIELab values $\left(\mathrm{L}^{*} ; \mathrm{a}^{*} ; \mathrm{b}^{*}\right)$ were not affected by the increasing enzyme dosage (data not shown). The total colour difference $\left(\Delta \mathrm{E}^{*}\right)$ was clearly visible $(\mathrm{x}>3.0)$ when reference was compared to $0.3 \%$ mTG-treated sample, recognisable $(1.5<\mathrm{x}<3.0)$ at $0.5 \%$ mTG level by frankfurters as well.

2.1.2. Extrusion and adhesiveness. The addition of $\mathrm{mTG}$ caused just a slight increase in the extrusion force of meat batter samples (Table 1). Interestingly, the adhesiveness of meat batters decreased significantly with the addition of mTG even at a very low level $(0.3 \% \mathrm{w} / \mathrm{w})$ and reached a negative peak at $0.5 \% \mathrm{mTG}$ concentration (not shown in this paper)

2.1.3. Water holding capacity. As for referring to WHC, the addition of $0.3 \% \mathrm{mTG}$ was the most favourable. The results, as shown in Table 1, suggest using rather less than $1 \% \mathrm{mTG}$ for such a product. The lipid oxidation was quantified by TBA-numbers (Table 1). It is clearly visible that the higher the enzyme content the more resistance to peroxidation occurred. 


\begin{tabular}{|c|c|c|c|c|}
\hline \multirow{2}{*}{$\begin{array}{l}\mathrm{mTG} \\
\text { Enzyme dosage, \% }\end{array}$} & \multicolumn{2}{|c|}{ Meat batter } & \multicolumn{2}{|c|}{ Frankfurter } \\
\hline & Extrusion force, $\mathrm{N}$ & WHC, $\mathrm{mm}^{2} \mathrm{mg}^{-1}$ & Hardness, $\mathrm{N}$ & $\begin{array}{l}\text { TBA-number, } \\
\text { MDA mg kg }\end{array}$ \\
\hline 0 & 15.8 & 3.1 & 9.6 & 11.5 \\
\hline 0.3 & 15.6 & 2.3 & 12.5 & 11.5 \\
\hline 0.5 & 16.5 & 2.8 & 17.5 & 10.0 \\
\hline 1 & 16.7 & 3.5 & 16.8 & 8.9 \\
\hline 2 & 16.1 & 3.5 & 12.7 & 5.7 \\
\hline
\end{tabular}

2.1.4. Hardness. Hardness is very important trait of frankfurters, as it is in close relation with crispiness (Fig. 1), one of the key features that consumers are really looking for. As seen in Fig. 2, enzyme addition led to visible change in the hardness of frankfurters. The best result was reached at $0.5 \%$ enzyme dosage.

2.1.5. Sensory analysis. Sensorial analysis showed that $\mathrm{mTG}$ enhances frankfurters in all of the measured attributes, and it was more liked (see overall acceptance) than the nontreated reference. According to the sensory scores, colour, crispiness, and spreadability were affected.

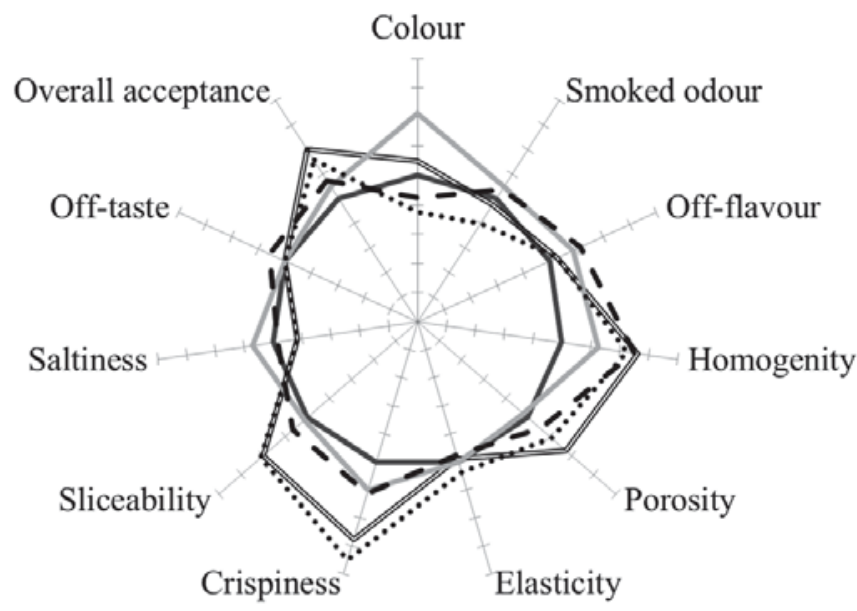

Fig. 1. Changes of sensorial properties with different enzyme dosage. - Reference;

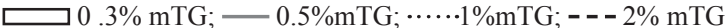

Our results show that $0.5 \% \mathrm{mTG}$ is promising for making frankfurters with conventional salt addition (1.8\%), but the effect of using less salt should also be investigated to know the needed and sufficient amount to produce healthier low-salt products. 


\subsection{Effect of salt content on frankfurters made with $0.5 \% \mathrm{mTG}$}

2.2.1. Surface colour. CIELab values (L*; $\left.\mathrm{a}^{*} ; \mathrm{b}^{*}\right)$ were not affected by the increasing salt content (data not shown). The total colour difference $\left(\Delta \mathrm{E}^{*}\right)$ was clearly visible $(6.0<\mathrm{x}<12.0)$ in frankfurters with both $1.4 \%$ and $1.6 \%$ salt levels (compared to non-treated reference), but at $1.8 \%$ salt concentration it was just recognizable $(1.5<\mathrm{x}<3.0)$.

2.2.2. Extrusion and adhesiveness. Extrusion force (Table 2) decreased with enzyme addition at both $1.4 \%$ and $1.6 \%$ salt levels, which means that in our case the enzyme withstands better the extrusion force than the reference only at $1.8 \%$ salt level, and the difference is not remarkable. Adhesiveness is following the same trend as extrusion (not shown in this paper), although the enzyme treated sample seemed to be less adhesive even at $1.8 \%$ salt level. This means for us that the mTG can make the meat batter more spreadable at all measured salt levels, which is very important at the filling step as it makes it easier.

Table 2. Effect of salt level on meat batter and frankfurters (average is shown). Results of reference are shown in brackets

\begin{tabular}{|c|c|c|c|c|}
\hline \multirow{2}{*}{$\begin{array}{l}\text { Curing salt } \\
\text { Salt level, \% }\end{array}$} & \multicolumn{2}{|c|}{ Meat batter } & \multicolumn{2}{|c|}{ Frankfurter } \\
\hline & Extrusion force, $\mathrm{N}$ & $\begin{array}{c}\text { WHC, } \\
\mathrm{mm}^{2} \mathrm{mg}^{-1}\end{array}$ & Hardness, N & $\begin{array}{l}\text { TBA-number, } \\
\text { MDA mg kg }\end{array}$ \\
\hline 1.4 & $9.5(10.8)$ & $3.6(3.1)$ & $15.3(6.4)$ & $0.13(0.14)$ \\
\hline 1.6 & $8.6(15.8)$ & $3.1(4.0)$ & $16.0(11.0)$ & $0.13(0.15)$ \\
\hline 1.8 & $16.5(14.3)$ & $3.5(3.8)$ & $17.5(9.6)$ & $0.14(0.16)$ \\
\hline
\end{tabular}

2.2.3. Water holding capacity. As seen in Table 2, the effect of $\mathrm{mTG}$ is not obvious if we consider the WHC. It seems to be more effective below $1.8 \%$ salt level, but further investigation is needed to determinate whether there is a tendency of resistance to peroxidation depending on the enzyme concentration.

2.2.4. Hardness. We may say that the effect of mTG was by hardness measurements the most obvious (Table 2). According to our data, mTG made frankfurters firmer at all applied salt levels as compared to the reference. It is also obvious that the hardness of the enzyme treated samples were just slightly affected by the different salt levels $\left(\mathrm{R}^{2}=0.9478\right.$, within a short interval: $14.45-16.25 \mathrm{~N})$.

2.2.5. Sensory analysis. Sensory evaluation (Fig. 2) revealed that enzyme-treated frankfurters made with $1.6 \%$ salt can substitute the $1.8 \%$ salt level, so it is unnecessary to use high amounts of salt if $0.5 \% \mathrm{mTG}$ is added. We state that according to our sensory panel, lower salt level can negatively affect the sliceability, crispiness, and elasticity of the product and that is why it is not recommended. 


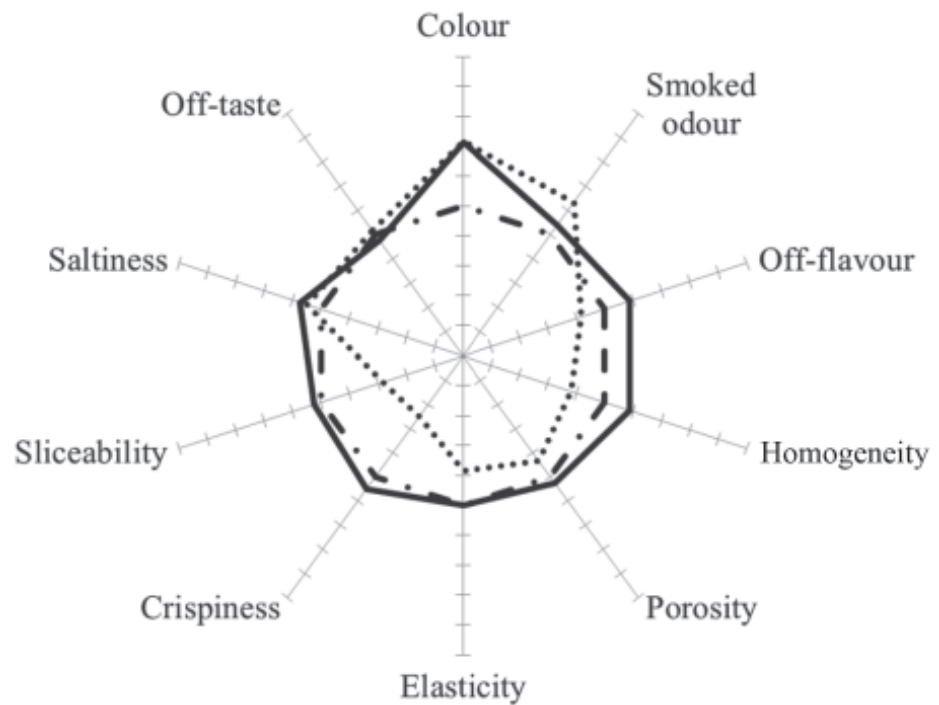

Fig. 2. Changes of sensorial properties with different salt content. $\cdots \cdot 1.4 \%$ salt; $-1.6 \%$ salt; $1.8 \%$ salt

\section{Conclusions}

It was established that low-salt (1.6\%) frankfurter with $0.5 \%$ mTG can be a good alternative to normal salted $(1.8 \%)$ frankfurter without enzyme addition, as its meat batter is easier to stuff $(46 \%$ less extrusion force needed, which means more springiness and $51 \%$ less adhesiveness, which means less sticking). The final product has better textural properties (66\% more hardness). Furthermore, the frankfurters treated with that amount of mTG have better storage stability, as its TBA-number was $18 \%$ less compared to the control.

We take this opportunity to express our profound gratitude and deep regards to János Molnár, chief executive of Jáner Hús Plc., who allowed us to do part of our research in the processing plant of Szigetszentmiklós, Hungary. We kindly thank Barentz Hungary Ltd. for providing the microbial transglutaminase used in this study.

\section{References}

Colmenero, F.J., Ayo, M.J. \& Carballo, J. (2005): Physicochemical properties of low sodium frankfurter with added walnut: effect of transglutaminase combined with caseinate, $\mathrm{KCl}$ and dietary fibre as salt replacers. Meat Sci., 69, 781-788.

Grau, R. \& Hamm, R. (1953): Eine einfache methode zur Bestimmung der Wasserbindung im Muskel. Naturwissenschaften, 40, 29-30.

LeE, H.C. \& Chin, K.B. (2010): Application of microbial transglutaminase and functional ingredients for the healthier low-fat / salt meat products: A review. Korean J. Food Sci. An., 6, 886-895.

Pikul, J., Leszczynski, D E. \& Kummerow, F.A. (1989): Evaluation of three modified TBA methods for measuring lipid oxidation in chicken meat. J. Agr. Food Chem., 37, 1309-1313.

Yокоуама, K., Nio, N. \& Kiкuchi, Y. (2004): Properties and applications of microbial transglutaminase. Appl. Microbiol. Biot., 64, 447-454. 